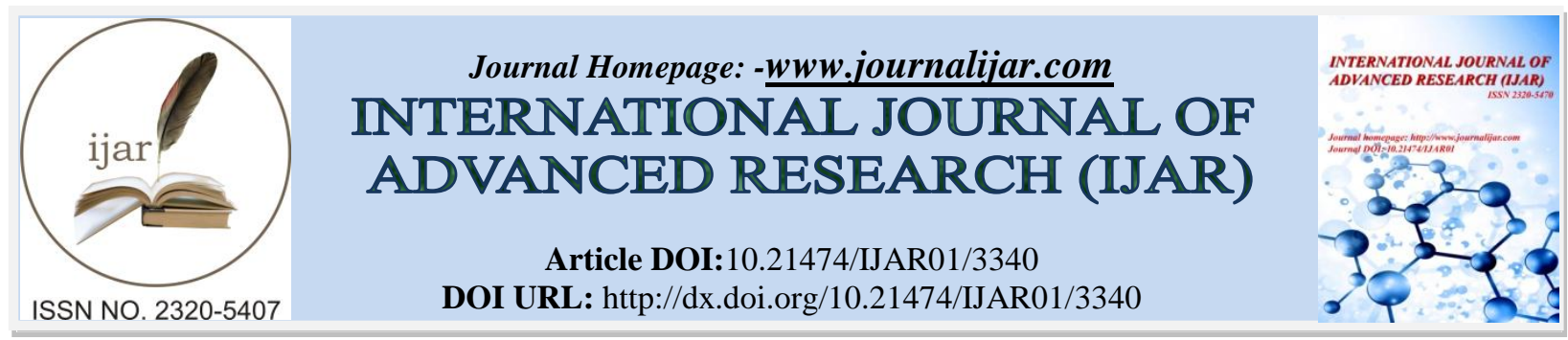

RESEARCH ARTICLE

\title{
CLASSROOM ACTION RESEARCH MANAGEMENT TRAINING MODEL FOR SENIOR HIGH SCHOOL TEACHERS AIDED BY E-MODULE.
}

Sadimin $^{1}$,Wahyu Hardyanto ${ }^{2}$, Achmad Slamet ${ }^{2}$ and Titi Prihatin ${ }^{2}$.

1. Doctorate Program of Educational Management of UNNES Postgraduate Program, The Headmaster of State Senior High School Brebes.

2. Educational Management Department of UNNES Postgraduate Program Indonesia

\section{Manuscript Info}

(..........................

Manuscript History

Received: 29 December 2016

Final Accepted: 16 January 2017

Published: February 2017

\begin{abstract}
This research is aimed at analyzing the factual model of classroom action research management training for Senior High School teachers which has been being used so far, and analyzing hypotactic model of classroom action research training aided by of E-Module for Senior High School teachers. Research and development were employed to pursue the early-mentioned problems. Meanwhile, the data collecting technique was done by interviews, documentation, observation, questionnaire, and test. Further, the result of the study showed that the final model of the classroom action research training aided by EModule was highly effective. The expanded trial results showed that the training model of Classroom Action Research with help of EModule was able to properly facilitate teachers to implement and compile Classroom Action Research reports independently and easily. Moreover, the E-Module of the Classroom Action Research helped teachers to understand the classroom action research. At last, the conclusion of this study shows that the Classroom Action Research training model aided E-module gives ease for teachers to conduct classroom action research since any participants can access the EModule via the browser.
\end{abstract}

Copy Right, IJAR, 2017,. All rights reserved.

\section{Introduction:-}

Classroom Action Research is one of ways which is beneficial for teachers to understand what happens to their class as well as possible solutions for it.

Asrori (2007:6) states that classroom action research is a reflective study which is done by doing particular treatments to improve the teaching and learning process in class to be better so that students could have good achievement in learning.

Hamdani (2011: 326), action research is essentially a scientific activity that is able to reflect learning activities in the classroom through scientific research that can be accounted to the procedures and requirements, which can be done without reducing teachers' attention in the classroom and student achievement. Furthermore, Agung (2012: 64) says that action research is a research conducted by educators, and also is a type of research that aims to give teachers 
opportunity to resolve the problems of teaching and non-teaching in the classroom carefully, systematically by using the existed rules.

\section{Gwynn Mettetal (2001:7) defines classroom action research as follows:-}

Classroom Action Research is a method of finding out what works best in your own classroom so that you can improve student learning. Meanwhile, Jean Mc Niff et al (2006:7) argues : Action research is a form of enquiry that enables practitioners everywhere to investigate and evaluate their work. They ask, 'What am I doing? What do I need to improve? How do I improve it? 'Their accounts of practice show how they are trying to improve their own learning, and influence the learning of others.

In fact, there are many teachers who have not implemented independently the classroom action research in order to improve the quality of learning and to the promotion of teachers. It was proven by the preliminary research which showed that teachers' competence in the understanding the classroom action research is still low. There are various possible causes for the low learning process conducted by the teacher. These possibilities include (1) lack of competence of teachers in the areas of classroom action research, (2) poor understanding of teachers to the benefits of classroom action research, (3) lack of competence of teachers in classroom action research, (4) there were only few products of Class Action Research produced by the teachers, (5) only few teachers promoted within the last 3 years.

In improving the quality of teaching and learning process at schools, it takes the ability of teachers to conduct classroom action research. Classroom action research is simple research that teachers do in analyzing the potential and weaknesses of the learning process. Ironically, the motivation of many high school teachers in Brebes to conduct classroom action research is still weak. This is due to ignorance of the teachers in conducting the research.

Since there are some lacks of classroom action research understanding, it is necessary to create any training model of classroom action research that can provide direct experience and real and not only emphasize the theoretical aspects, but also provide the opportunity for teachers to have applicative competence that will be able to produce competent and professional teachers. Therefore, it is necessary to develop a way of solving the problem by creating a training model of classroom action research aided by E-module, so the high school teachers' professionalism in Brebes can be improved and the promotion of teachers can be regularly implemented.

The problem in this research is how is the realization of the factual models of Class Action Research trainings that have been organized for high school teachers, how is the design of hypothetical model of classroom action research training aided by E-Module for high school teachers, how is the final models of classroom action research training using E-Module for high school teachers.

The purpose of this study is to analyze the factual models of classroom action research training for high school teachers that have been implemented over the years, analyzing the hypothetical model of classroom action research training aided by E-Module for high school teachers, analyzing the final model of classroom action research training aided by E-Module for high school teachers.

The Classroom Action Research Training aided by E-Module is done as part of efforts to facilitate teachers to improve the quality of learning and write proposals and classroom action research reports with hope that they can do it easily and independently. This training will provide convenience for teachers in preparing proposals and reports of classroom action research. The teachers will have the knowledge and skills in preparing proposals and reports of classroom action research. Moreover, the teachers will also have positive attitude (motivation) to implement innovation in teaching. Thus, the training of classroom action research aided by E-module is a training model that has high efficacy to facilitate the teachers effectively in preparing proposals and reports of classroom action research. This is in accordance with the opinion of Sharma (2013: 16) that the effectiveness of the training is the extent to which participants can learn and apply knowledge and skills acquired during the program. This is influenced by attitudes, interests, values and expectations of trainees and training environments. It is said to since the advantages of online learning resources as learning media have been demonstrated convincingly by several studies.

For the purposes of the implementation of learning, the government through relevant educational institutions has provided teachers with classroom action research training to improve the quality of learning. The training is learning 
that is set to improve the current working performance. Meanwhile, training, according to the concept of state administrative agencies, gives more emphasis on the process of improving the ability of an individual in carrying out his duties (Admodiwirio, 2002: 35).

Training according to Nadler (1982), is a learning process that is prepared to improve the performance of a job in hand. Nadler emphasizes on human resource development. Meanwhile, training according to Rothwell (2003: 352) is an organized learning activities aimed at improving individual performance through changes in knowledge, skills, or attitudes. In a broad sense, the training is intended to meet the essential job requirements, update skills, to prepare people to improve career, improve knowledge and skills, as well as generate new insight or even create new knowledge.

According to Sulistiyani (2009: 219) training is a systematic process of changing the behavior of the employees in a direction to improve organizational goals. According to Mendoza (2009: 2) the purpose of training in a work situation, is to enable individuals to acquire the ability (competence), so that he can perform a given task or job adequately.

As according Meldona (2009: 238) the benefits of holding the training are: (1) To assist the development of skills a person, (2) To help improving the efficiency, effectiveness, productivity and quality of work, (3) Meet the personal needs of participants, (4) Improving working knowledge and expertise at all levels, (5) Transfer of knowledge and new knowledge.

Research conducted by Alomari (2009) showed that the online-based learning resources can support students' ability to gather information as a source of learning materials. The use of online learning resources is therefore not only beneficial for interactivity and accessibility, but also can enhance the independence of the students actively in learning.

Arani (2004) found that the use of online learning resources is more effective than traditional methods by delivering a lecture in front of the class. In addition, the development of e-book technology encourages the blend of print technology with computer technology in learning activities. Various printed instructional media, one of which is module, can be transformed into electronic form, hence that's the history of the electronic module or known as the emodule. There is no definite definition of the electronic module so far. With reference to the various terms associated with the electronic module, it can be defined that the electronic module is the incorporation of the term module which takes the form of electronic learning (e-book).

The results of this study are expected to provide benefits such as: product with the construction of a training model of classroom action research aided by E-Module for high school teachers. The successful training model developed is expected to be used as reference material in similar studies in the future. Thus, there will be any development of other types of products such as E-Module that provides convenience facilities for teachers in writing proposals and reports of classroom action research easily and independently, produces training packages in the form of: training, training manuals, guidebooks trainer, instructor guide books, e-training modules. Those training packages are expected to be a guide for the organization of training.

\section{Research Method:-}

This study used research and development (Research and Development). According to Borg and Gall (2007: 590), R $\&$ D has the following characteristics: (1) conduct preliminary research to find relevant facts regarding the products to developed; (2) develop products based on the findings of the research; (3) do field test in the settings or actual situations where these products will be used; (4) do revision to correct the weaknesses found in the stages of field testing.

The selection of Research and Development design (R \& D) in this study was based on research objectives, namely to produce a training model of classroom action research aided by E-Module. The model of the development of this study consists of four stages, namely: (1) a preliminary study to obtain information on training model of classroom action research ever conducted, followed by an analysis of the strengths and weaknesses of the model; (2) development of a model training classroom action research aided by E-Module; (3) validation of the Class Action Research training model aided by E-Module by experts and practitioners; (4) test the training model aided by EModule. 
The subjects in this study were high school teachers in Brebes. In this case the sampling for the study subjects was performed through cluster sampling and quota sampling. In this study, for the purposes of FGD, the researchers involved 15 high school teachers in Brebes district. For the testing purposes, the researchers limited the subject of the study to 10 high school teachers who come from high schools in Brebes district. To the expand the test, there were 25 teachers from various high schools in Brebes district.

The data collecting technique in this training is by having interviews, questionnaires, documentation, testing, and observation. Thus, the instruments used to collect research data is the questionnaire, documentation questionnaire, test, and observation sheet.

\section{Results and Discussion:-}

\section{Results:-}

In order to be able to develop a training model according to the needs of participants, it is necessary to analyze the quality of the previous trainings and do need analysis on the training from the teachers or participants of the training.

From the preliminary study on the quality of the previous training of Classroom Action Research, the teachers gave the following feedback: (1) $63.31 \%$ for the design of the training; (2) $64.90 \%$ for the training program; (3) $63.08 \%$ training materials; (4) $67.98 \%$ for training instructors; and (5) $64.20 \%$ for facilities and infrastructures.

Further, there is a need to develop training model of the Classroom Action Research aided by E-Module. Moreover, the results of the preliminary study which were aimed at uncovering the needs of teachers to classroom action research training gained average percentage of responses as follows: (1) the design of the training achieved $89.07 \%$ responses; (2) the training program achieved $86.79 \%$ responses; (3) training teaching material achieved $86.86 \%$ responses; (4) Training instructors achieved $88.78 \%$ responses; and (5) facilities and infrastructures achieved $86.80 \%$ responses.

By consideration the results of the field studies and the results of teacher responses towards the quality of the previous trainings and the training needs, it is necessary to develop a training model of Classroom Action Research aided by E-Module.

The current factual model of Class Action Research training used for the previous trainings is considered lack of sufficient competence for participants to develop proposals and Classroom Action Research reports independently. Therefore, the findings of the preliminary study can be seen in Figure 1. 


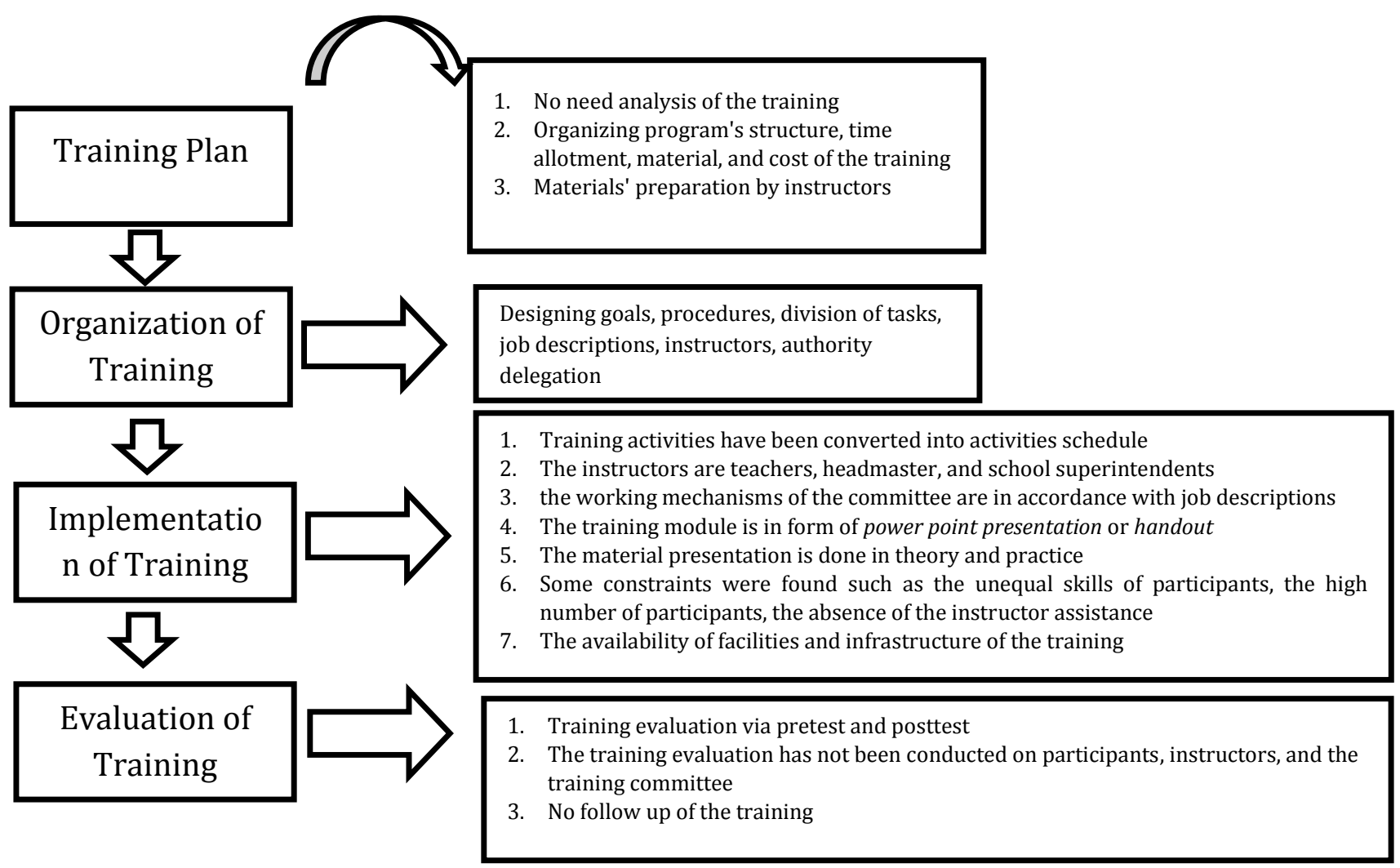

Figure 1:- The Factual Model's Scheme of Classroom Action Research Training

By taking into consideration the results of field studies and the results of teacher responses regarding the quality of previous trainings and the training needs, it is necessary to develop a training model of Class Action Research aided by E-Module by creating hypothetical model. The development hypothetical model of classroom action research aided by E-module training consists of three major parts: (1) introduction; (2) Design Classroom Action Research training model aided by E-Module; and (3) The closing section. Therefore, the Hypothetical model of classroom action research training aided by E-Module can be seen in Figure 2. 


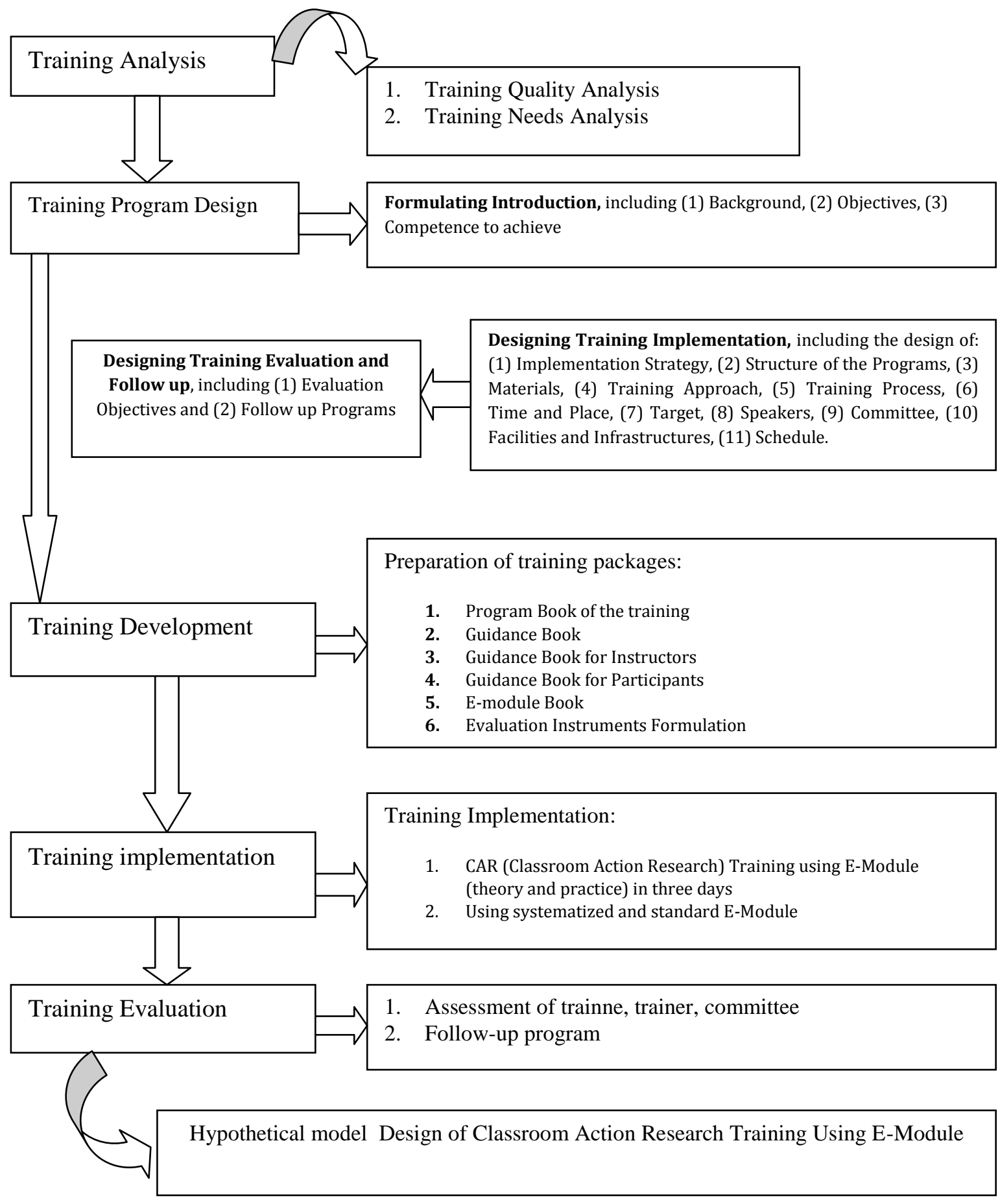

Figure 2:- The Hypothetical Model's Scheme of Classroom Action Research Training Using E-Module

To get the expected final training model, then, there was a trial on the hypothetical model. This trial was conducted with a limited field testing in the form of model implementation training for high school teachers. Again, this trial began with a test on a small group. In this case the small group trial was done once by the aim to simulate the application of the model and got an overview of the implementation of the limited field testing. The trial test was conducted on a small group of teachers who had never received training of classroom action research and were seen to have basic knowledge of classroom action research aided by E-Module. The aim of this trial was to obtain 
feedback from teachers on the level of readability and feasibility of the training of Class Action Research aided by E-Module. Further, the responses of teachers of this trial were as follows.

The result of the trial treatment achieved $86.33 \%$ for the responses to the development of the Classroom Action Research aided by E-Module. This percentage of responses means that the development of the Classroom Action Research E-Module was considerably good. Meanwhile, the previous average percentage was derived from responses to the aspect, of page display which amounted to $88.50 \%$, in response to the introduction which amounted to $84.17 \%$, in response to the core aspects of the module by $85 \%$, in response to aspects of the closing matter by $85 \%$, and responses to aspects of bibliography of $90 \%$.

The researchers also got inputs form the above-mentioned trial, namely the need of the availability of alternative answer to the exercise so that any wrong answers can be corrected and replaced by other alternative answers, the need of E-Module manuals, instructional videos and examples of proposals. Thus, there is a need to complete the EModule.

After going through the stages of small group trial, the trial was continued to the limited field test. This limited field test was intended to determine the extent of the effectiveness of the training model of Classroom Action Research aided by E-Modules being developed. The indicators of the effectiveness were seen from the increase in teachers' knowledge, skills in writing proposals of Classroom Action Research, and positive attitudes towards the implementation of the Class Action Research training aided by E-Module.

As explained earlier, the extended field tests were carried out in the form of classroom action research training aided by E-Module for high school teachers in Brebes district. In this implementation, there were 25 teachers involved. The teachers were the representatives of various high schools in the district Brebes derived from state Senior High School. In addition, the venue of training was at SMAN 2 Brebes.

In the expanded field test, there was an activity conducted namely the practice of classroom action research proposal writing aided by E-Module. In this training, teachers were given an understanding on how to prepare proposals and reports of Classroom Action Research Action Research aided by E-Module. Through the E-Module, the teachers could write and organize the proposals and reports of classroom action research with ease and independence.

During the implementation of the Class Action Research Training aided by E-module, the teachers were given a briefing in the form of how to install and use the E-Module with the existing guidance. After the briefing, the teachers were mentored and guided to the practice and the implementation of the Classroom Action Research and proposal drafting aided by E-Module. Meanwhile, the training activities were guided by an instructor using an LCD projector. Further, the training approach used was an interactive discussion that created a conductive training environment.

In an effort of knowing the effectiveness of the training model of Classroom Action Research aided by E-Module, pre-test and post-test were given to the trainees. On the one hand, for the purposes of pre-test and post-test there had been set up 25 test items. The test items had been through the stages of expert validation and FGD was well as the validity and reliability test items as described in the early section. Meanwhile, to describe the skills of the teachers in the training, then the observations on the ability of teachers in preparing classroom action research proposal were done. Alternatively, to determine the attitudes of the teachers towards the training, the data collection was done through questionnaires attitude. The limited field trial activities were also done to determine the response of the teachers to the implementation of the training in general and the response to training packages developed through the questionnaire.

Data obtained from the pre-test and post-test were then analyzed with the help of SPSS.I6 program. Meanwhile, the observation data of the skills and attitudes of the teachers on the implementation of the training and the training packages were analyzed with the help of MS Office Excel 2010 program.

The average value of pre -test was 15.28 with the percentage of achievement was $61.12 \%$. Meanwhile, the highest score was 20 and the lowest score was 10 . The number of participants who were able to achieve $50 \%$ percentage were 21 participants and participants who reached the percentage of achievement above $75 \%$ were as much as 3 people. 
The average score of post-test was 20.04 with the achievement percentage of $80.16 \%$. Meanwhile, the highest score was 24 and the lowest score was 17. Again, the number of participants who were able to achieve the results $50 \%$ were 25 participants and percentage of achievement which resulted above $75 \%$ were a total of 17 participants, or $68 \%$ of all participants who amounted 25 people.

Based on the results of the pre-test, it is known that the teacher's knowledge of classroom action research before training was generally good that is with an average of 15.28 or the average percentage score of $61.12 \%$. However, not all participants could understand Classroom Action Research well. Meanwhile, the post-test result illustrated that there was an increase of teacher knowledge of classroom action research. It is proven by the average scores achieved namely 20.04 or with an average percentage of $80.16 \%$ of the achievement results. This post-test results indicate that there is an increased knowledge of teachers in the classroom action research after the classroom action research training aided by E-Module.

In order to determine the effectiveness of the training model, so the derived data and pre-test and post-test results were calculated using t-test in SPSS.16 program. However, before the t-test was carried out, the researchers did homogeneity test first. Homogeneity test is intended to determine whether the obtained data are derived from a homogeneous sample. After the homogeneity test was done, it resulted value of significance amounted to 0.209 . The sig-hit value of the homogeneity test was greater 0.05 than the significant level which is $5 \%$. The results of this analysis prove the data of pre-test and post-test obtained came from homogeneous sample. Furthermore, the t-test with SPSS.16 program could be conducted.

By using SPSS, the t-test results were as follows: (1) the average test scores (mean) got improvement before and after the training, namely from 15.28 into 20.04 . From the mean value, it can be seen that the teachers' competencies increased having the training by using the training model of classroom action research aided by E-Module; (2) The standard deviation showed that the heterogeneity occurred in the data before and after the training were 2.76164 and 2.05102; and (3) the standard error of the mean before and after training were 0.55233 and 0.41020 . Further, the standard error of the mean describes the distribution of the sample average of the average of the average of all possible samples.

After the data being tested using t-test with paired samples correlations models, the results of sig-hit of 0.00 and a correlation value of 0.675 . Meanwhile, the analysis of paired samples with correlations is an analysis aimed at showing the relationship between the average value of pre-test before training and the value of post-test after the training sessions for the teachers. Based on the results of t-test with of paired samples model, the result showed that the correlations of Sig.count was smaller than $\alpha$, that was Sig. count $(0.000)<\alpha(0.05)$. Therefore, it can be concluded that there was a significant relationship of the teacher competence before the training and after the holding of the training. Again, the strength of the correlation could also be seen in the amount of 0.675 which indicates that the data of the pre-test and post-test had a very strong correlation.

Based on t-test results, it is known that the training given to teachers by using classroom action research training model aided by E-Module provided a significant effect on improving the competence of the teachers in implementing classroom action research. This illustrates that the training model of classroom action research aided by E-Module is a training model that suits the teachers in doing and preparing classroom action research report.

Based on the t-test with a model of paired samples t-test, the t-count was obtained by -11.627 and sig.count as many as 0,000 . The t-test model with paired samples test is intended to determine whether there are differences between the data derived from the pre-test with data derived from the post-test. Further, the results of the analysis using t-test were then compared with t-table value. The t-table value was derived from number of participants which were as many as 25 participants and further can be seen in the t-table which showed value of 2.064. By comparing the value of t-count and t-table, it is seen that t-count <t-table. It also appears that Sig.count had a significant difference between the pre-test and post-test scores and the participants.

The existence of significant differences between the pre-test and the post-test scores in training activities of Classroom Action Research aided by E-Module indicates that the training model of classroom action research aided by E-Modules being developed is capable of providing improvement on the knowledge of the teachers in implementing and compiling reports of classroom action research. Moreover, by looking at the differences in mean 
of the pre-test and post-test, it can be seen that the model of classroom action research aided by E-Modules provides great impact for the improvement of the teachers' competence in the understanding of classroom action research.

The results of observations of the skills of teachers in preparing classroom action research proposal resulted the average percentage of $82 \%$. These results came from the observation of the aspects of the writing skills of the title of $83 \%$, observations of the introduction aspects of writing skills by $84 \%$, observation of the aspects of the writing skills of the theoretical framework of $80 \%$, and the observation of the aspects of the writing skills of research methods by $81 \%$.

Based on the observation of the skills, it showed that most trainees already had skills in preparing the proposals of Classroom Action Research. The capability achieved by the participants came as the result of the application of the Class Action Research training model aided by E-Module. Thus, the Class Action Research training model aided by E-Module effectively provides knowledge and skills to the teachers in implementing and developing a proposal of Classroom Action Research.

These results are in accordance with the opinion of Sharma (2013) who states that the effectiveness of the training is the extent to which participants can learn and apply knowledge and skills acquired during the training program. The increase in knowledge and skills of the teachers in preparing classroom action research proposal is expected to have an impact on teacher professionalism so as to manage an active and interactive learning as well as to be able to foster learners to achieve optimal success.

This is in accordance with the opinion of Orlich (2010), who states that the functional level the teaching profession in learning is largely determined by the attitude showed by teachers towards students whether they could create any interactions or not. Therefore, the highest level of teachers' professionalism are showed by deliberately creating, and placing the top priority on the success of learners.

\section{Discussion:-}

The expanded trial results showed that the training model of Class Action Research aided by E-Module is able to properly facilitate the teachers to organize proposals and reports of Classroom Action Research independently and easily. As a matter of fact, the E-Module of Classroom Action Research helped the teachers in understanding Classroom Action Research. This is understandable because the E-Module of Classroom Action Research is accessible anywhere and anytime via the Internet.

The results of this study illustrate that the training model of Class Action Research aided by E-Module had a high important effectiveness. This model will be able to assist teachers in implementing and compiling the reports of classroom action research. It is certainly very helpful for those who do not have sufficient ability to carry out classroom action research, thereby inhibiting teachers in improving the quality of learning.

The high effectiveness of the training model of Class Action Research aided by E-Module was reflected in the high percentage of achievement of the teachers' skills in preparing proposals of Classroom Action Research, the mean difference better between pre and post-test happened for the training model of Class Action Research aided by EModule was capable of bridging between the teachers' needs and the limited ability of teachers in implementing classroom action research. In this case the teachers had the ease of preparing the report of Classroom Action Research independently with help of the E-Module.

The attitudes' survey towards training teachers obtained an average percentage of $85.17 \%$. Besides, the participants' responses which amounted to $85.17 \%$ illustrates that the attitude of the participants towards the training of classroom action research aided by E-Module was very good. Additionally, the results achieved was derived from observation of the aspects of honesty by $82.3 \%$, from the observation of the aspects of the discipline of $83 \%$, observation of the aspect of responsibility by $83 \%$, observation of the aspects of tolerance of $92 \%$ observations on aspects of cooperation by $80 \%$, observations of the politeness amounted to $95.80 \%$, and observations on aspects of confidence of $80.1 \%$.

The attitude's observation illustrates that participants strongly agree on the development of the training model of Classroom Action Research aided by E-Module. It should also be understood that the training model of Classroom Action Research aided by E-Module has been able to provide facilities for the teachers in implementing classroom 
action research so that the teachers were able to compile the reports of classroom action research independently and easily. Actually, the high percentage of the response of the trainees' attitudes towards the training model also illustrates that the training model of Classroom Action Research aided by E-Module was developed according to the needs of teachers.

These results are in accordance with the opinion of Sharma who states that training's effectiveness is influenced by attitudes, interests, values and expectations of trainees and training environments. The training program will likely be more effective if participants have strong desire to learn, engage optimally in their work and have a career plan.

Based on the analysis and discussion of the score of the pre-test and post-test, analysis of the results of the observation skills of the trainees, and the observation of the attitude of the trainees towards the implementation of the training, it can be concluded that the training model of Classroom Action Research aided by E-Module has very high level of effectiveness. In other words, the model training of classroom action research aided by E-Module is very effective to provide skills for the teachers in preparing classroom action research report independently.

The magnitude of the effectiveness of the training model of Classroom Action Research aided by E-Module is also reflected from the participants' responses to the implementation of the training which was of $88.40 \%$ or achieved very good predicate. The participants' responses came from the responses to the aspects of the development of the training model by $88 \%$, response to aspects of training administration by $87 \%$, in response to the trainers of $87.10 \%$, and the response to the training's supporting facilities and infrastructures as well as the consumption amounted to $88.40 \%$.

The high response to the development of the training model of Classroom Action Research aided by E-Module shows that the training program was developed according to the needs of the teachers. Moreover, the training model of Classroom Action Research aided by E-Module was designed in form of activity practices of Classroom Action Research's proposal preparation with the time allocation of $80 \%$ of the total time available in the training. Also, the training model of Classroom Action Research aided by E-Module is supported with training packages in the form of a training guide books. At last, the implementation of the training model of Classroom Action Research aided by EModule for high school teachers was in accordance to the design being developed, namely with $80 \%$ in the form of the practice of classroom action research's proposal preparation.

The validation of the developed training model came in a bundle with the training packages. This validation was in the form of teachers' feedback through questionnaires.

The results of teacher responses to the training program achieved the average percentage of $89 \%$. This results indicates that the early part of the program was designed with interesting title, contains a preface which is in accordance with program's contents, and contain the table of contents which correspond to the program's contents. The introductory part of the program has compatibility between the background to the training objectives, has a description of conformity with the goals of training, and has suitable texts which explain the competencies to achieve in the training.

The teachers' responses to the development of the participant guide books provided average percentage of $85.84 \%$ or got a very good response. The high response of the teachers to guide books of participants suggests that the development of the guidebooks have systematical suitability in accordance with the training programs.

The response of the teachers to the training modules provided an average percentage of $85.84 \%$ response, which means that it got very good feedback. This illustrates that the development of the training manuals got a good response.

The trainee teachers' responses to the E-Module of Classroom Action Research provided information on average of the percentage of responses for $85.84 \%$, which means it got very good feedback. The high response indicates that the development of the E-Module of Classroom Action Research was in accordance with the needs of participants in the training.

Based on the discussion of the results and analysis of the pre-test and post-test, observation on the skills and attitudes survey of the teachers and the teachers' responses to the development of the training packages, it can be 
concluded that the development of the training model of Classroom Action Research aided by E-Module has a very high effectiveness.

This is in accordance with the opinion of Sharma (2013) who states that the effectiveness of the training is the extent to which participants can learn and apply knowledge and skills acquired during the training program. In this case, the teachers who joined the training model of Classroom Action Research aided by E-Module have gained good knowledge and skills so as to be able to carry out Classroom Action Research and compile its reports. Therefore, the final model of the training model of Classroom Action Research aided by E-Module can be seen in Figure 3 .

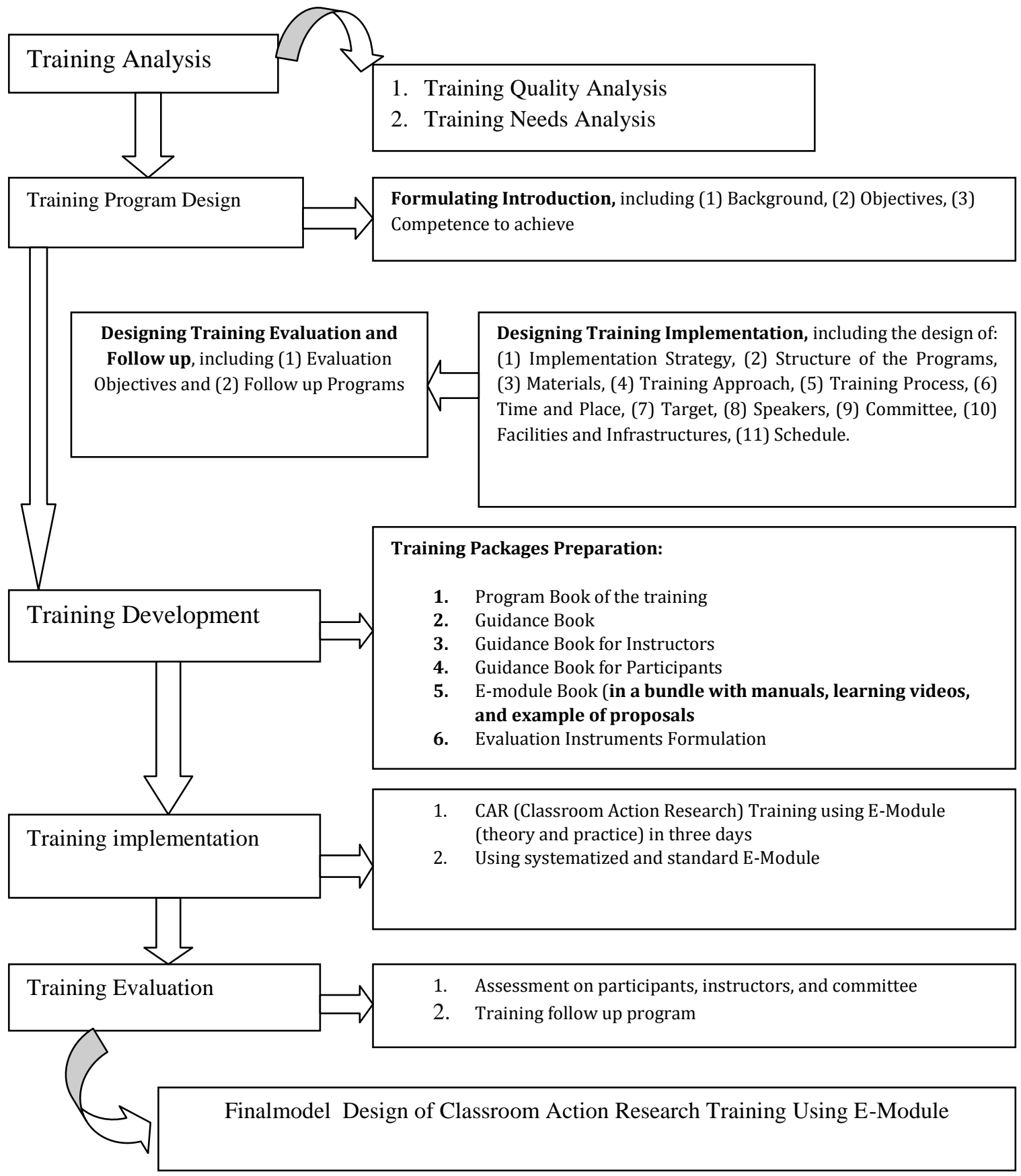

Figure 3:- The Final Model's Scheme of Classroom Action Research Training Using E-Module 


\section{Conclusions:-}

The training model of Classroom Action Research aided by E-Module is a training model that makes it easy for teachers to conduct classroom action research since the module are accessible for the participants via browser.

The training model of Classroom Action Research aided by E-Module is proved to have a high level of effectiveness. It is seen from (1) t-test results which showed significant difference between pre-test and post-test, the scores of the pre-test and post-test illustrates the increased knowledge of teachers about classroom action research, and the results correlation counting which presented that there was a significant relationship between pre-test and post-test; (2) The results of observations showed that the training model of Classroom Action Research aided by EModule has provided an improvement on the skills of the teachers in preparing classroom action research proposal; (3) The results of the observations of the attitudes of teachers showed that teachers have very good attitude towards the training model of Classroom Action Research aided by E-Module; (4) The results of the teachers' responses to the implementation of the training are generally known that the teachers responded very well to the training event; (5) The results of the teachers' responses to the developed training packages showed that all the packages being developed received very good response from the participants.

\section{References:-}

1. Agung,Iskandar, 2012, PanduanPenelitianTindakanKelas.Jakarta: BestariBuanaMurni.

2. Admodiwirio, 2005, Soebagio, ManajemenPelatihan. Jakarta :Ardadizya Jaya.

3. Alomari, Akram, 2009, Investigating online learning environments in a web based math course inJordan. International Journal of Education and Development using Information and Communication Technology (IJEDICT), 2009, Vol. 5, Issue 3, pg. 19-36

4. Arani, Askari, The effect of ICT-based teaching method on medical students' ESP learning [versielektronik]. Juornal of Medical Education, winter 2004, Vol 4, No.2

5. Asrori, M, 2007, PenelitianTindakanKelas. Bandung : CV Wacana Prima.

6. Borg. W. R and Gall, Meredith, D, 2007, Education Research: An Introduction New York: Longman Inc.

7. Gwynn Mettetal, 2001, The What, Why and How of Classroom Action Research. The Journal of Scholarship of Teaching and Learning (JoSoTL), Vol. 2, No. 1 (2001) pg. 6-13.

8. Hamdani, 2011, StrategiBelajarMengajar. Bandung: CV PustakaSetia.

9. Jean McNiff\&Jack Whitehead, 2006, All You Need to Know about Action research. London: SAGE Publication.

10. Meldona, 2009, ManajemenSumberDayamanusia, UIN-Malang Press, Malang.

11. Mendoza, R. R, Designing Training Programs For Professionals. www.picpa.com.ph, 2009, Downloaded on 17 February 2013.

12. Nadler, L, 1982, Designing Training Programs. The Critical Events Models. London: Addison-Wesley Publishing Company.

13. Orlich, D. C, at, al, 2010, Teaching Strategies A Guide To Effective Instruction. Boston USA: Wadsworth, Cengage Learning.

14. Rothwell,W,J\&Kazanas,H,C, 2003, Planing and Managing Human Resources Strategic Planing For Human ResourchesManagement.Massachusetts : Published by Human Resource Develompment Press,Inc.22 Amherst Road Amherst.

15. Sulistiyani. A. Teguh\&Rosidah , 2009, ManajemenSumberdayamanusia. Jakarta: Grahallmu

16. Sharma, Tejinder. 2013. Manajemen Training \& Development,2009. http.www.ddegjust.ac.instudymaterialmbaobh-412.pdf (downloaded on 21 June 2013) 